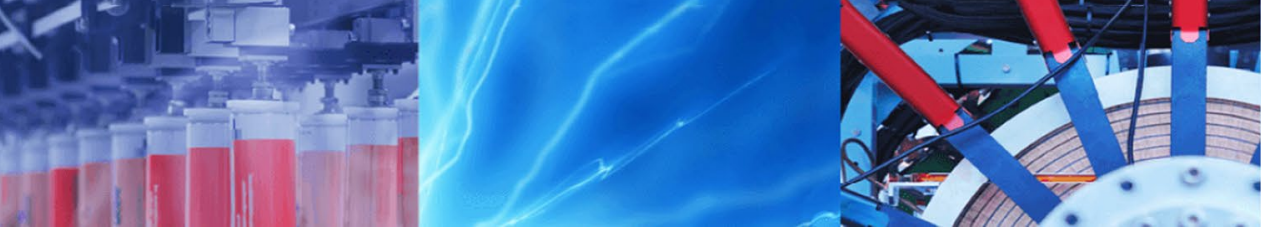

Case Study

\title{
Applying integrated remote sensing and field-based approach to map glacial landform features of the Machoi Glacier valley, NW Himalaya
}

\author{
Ishfaq Ahmad Pall ${ }^{1}$. Gowhar Meraj ${ }^{1,2}$ (D) Shakil Ahmad Romshoo ${ }^{1}$
}

(c) Springer Nature Switzerland AG 2019

\begin{abstract}
Glacial landforms are important precursors of landscape's glaciological history. Such evidences are vital to understand the role of climate in shaping the earth's surface. The work presented in this paper is about the detailed geomorphological mapping of the Machoi Glacier valley in NW Himalaya in Drass, Jammu and Kashmir. The geomorphological map of the area at 1:6000 scale was generated by integrating detailed field data, collected using Global Positioning System and electronic total station, and the satellite remote sensing information. Most of the area was mapped on field; however, some inaccessible areas were mapped using high-resolution DigitalGlobe QuickBird imagery. Various landform features mapped in the study area include lateral and terminal moraines, serrate, basin ridge, crevasses, glacier accumulation and ablation, debris cones, drumlins, horn and outwash plain. The spatial information on the glacial landform features in the area is aimed to guide the reconstruction of paleo-glaciological setup using dating techniques and will ultimately improve the knowledge gaps about the glaciation in the NW Himalaya during the Pleistocene.
\end{abstract}

Keywords Geomorphology · Electronic total station (ETS) · Global Positioning System (GPS) · Remote sensing · Geographic information system (GIS)

\section{Introduction}

Information about glacial landforms and landscapes advances our knowledge of glacial processes and their interactions with ice and climate dynamics $[15,17,26$, 28]. According to Blaszczynski and Bishop and Shroder $[3,5]$, geomorphological mapping is of prime importance for understanding different stages of geochronology and landscape evolution of the earth. Harbor [12] defines the principal role of geomorphology as the description and explanation of the impacts that glaciers and ice sheets have on the development of the glacial landforms. Napeiralski et al. [21] demonstrated its applicability in the assessment and analysis of the spatial distribution and temporal evolution of the glacial landforms at various scales. Most of the studies on the geomorphology focused only on glacier extent and behavior during the Holocene and the Little Ice Age $[22,26]$, but with the recent advancement in radiometric dating techniques and geomorphological mapping, dating of older ice extents have been reported $[6,8,33]$.

Glacial processes operating in the area are well preserved in the form of glacial sedimentary facies. Mapping of glacial features, when combined with dating techniques, provides the foundation for reconstructing and modeling past glacier dynamics. In other words, it provides spatial and temporal patterns of ice extent used to constrain paleo-climate variations $[10,28]$. Such investigations in Greater Himalaya have yield local chronologies and a comprehensive picture of last glacial maximum (LGM) [20].

In the context of Indian Himalaya, geomorphological studies have revealed significant variation in the

$\checkmark$ Gowhar Meraj, gowharmeraj@gmail.com; Shakil Ahmad Romshoo, shakilrom@yahoo.com | ${ }^{1}$ Department of Earth Sciences, University of Kashmir, Hazratbal, Srinagar, Jammu and Kashmir 190006, India. ${ }^{2}$ Department of Ecology, Environment and Remote Sensing, Government of Jammu and Kashmir, Srinagar, Jammu and Kashmir 190018, India. 
microclimates of different glacial basins that have similar paleo-climate conditions $[2,8,24]$. The present study is a first report on the geomorphological reconstruction of the Machoi Glacier valley in the NW greater Himalaya aimed at improving our understanding of paleo-climate of this part of the Himalaya. We carried out detailed field-based geomorphological mapping of the Machoi Glacier valley using GPS and ETS and used high-resolution QuickBird satellite imagery for mapping the inaccessible areas in the valley. The main goal of this paper is to set the mapping basis of dating in the study area in order to reconstruct the past climate besides quantifying number and dimensions of various glacial landform features.
Machoi Glacier valley $\left(34^{\circ} 16^{\prime} \mathrm{N}, 75^{\circ} 32^{\prime} \mathrm{E}\right.$, Drass, Jammu and Kashmir) is a small NNW-sloping glacier valley of NW Greater Himalaya, nearly $26 \mathrm{~km}$ from Sonamarg, on the right side of the Srinagar-Leh National Highway (Fig. 1). The valley covers an area of about $12.36 \mathrm{~km}^{2}$, having a length of $6.50 \mathrm{~km}$. The general trend of the valley is NNW-SSE with slope ranging from $20^{\circ}$ to $70^{\circ}$, and dominant aspect is north. This glacier is probably the only glacier in the Himalaya, which has, practically, a continuous photographic record of the snout (glacier front) since 1875 AD [27].
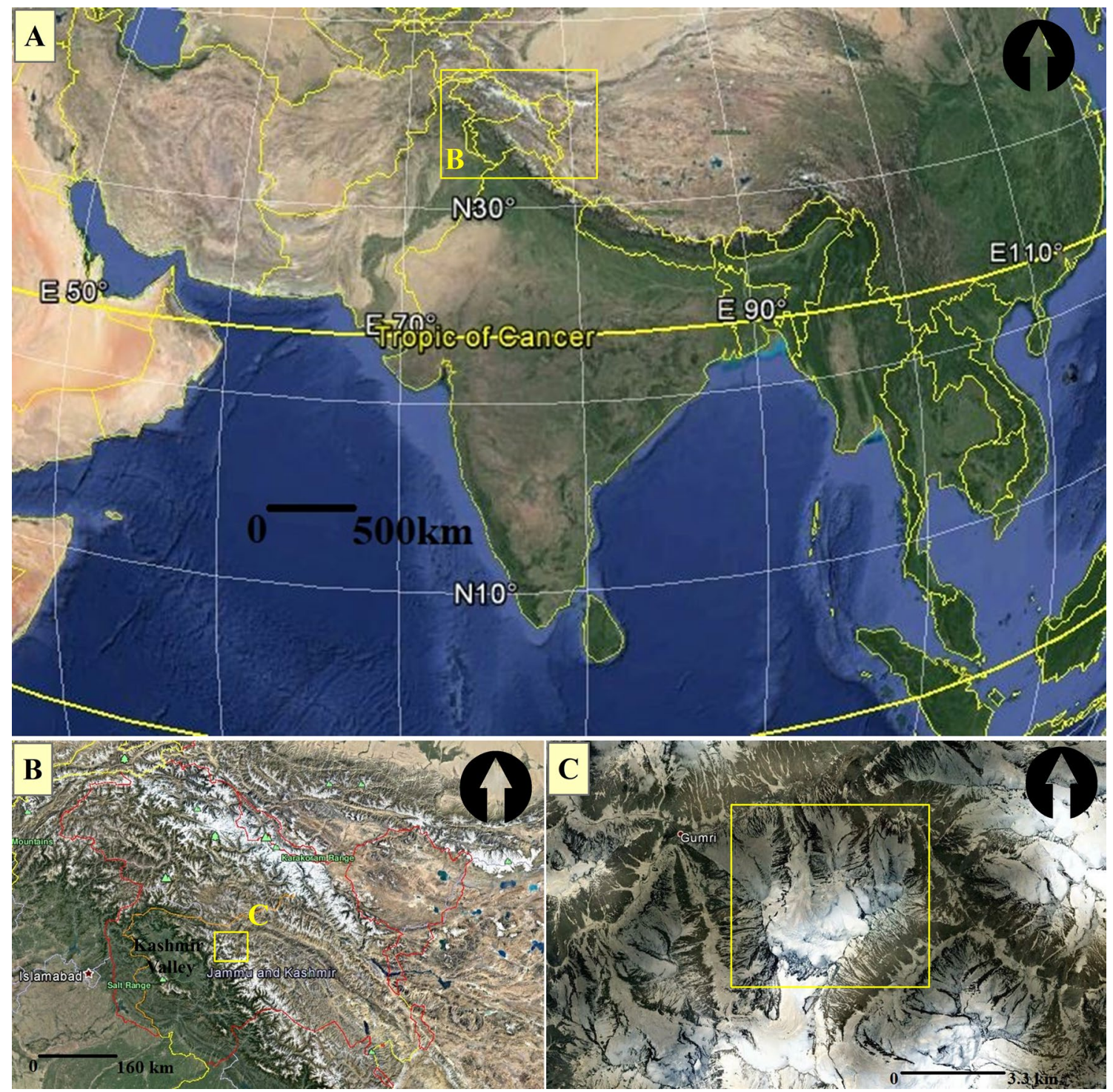

Fig. 1 Location map: a The location of India in relation to continent Asia; b The location of Jammu and Kashmir, the northern most state of India; c The location of Machoi valley (Yellow square) east to Kashmir valley; note the location of the nearby settlement, Gumri is shown. The map coordinates are in the UTM 43 (North) World Geodetic System (WGS-1984) reference system

\section{SN Applied Sciences}




\section{Materials and methods}

The mapping of glacial landforms of the Machoi Glacier valley was carried out during extensive field work in September-October 2014. The field equipment used was electronic total station (ETS, Trimble S6 DR+) and Trimble Explorer Global Positioning System (GPS) with an accuracy of $\pm 5 \mathrm{~m}$ for vertical $(z)$ and $\pm 3 \mathrm{~m}$ for horizontal $(x, y$ directions). ETS is an electronic theodolite (transit) integrated with an electronic distance meter (EDM) to read slope distances from the instrument to a particular point. Figure 2 shows the operation of the field equipment in the valley.

Measurement of distance by this equipment is accomplished with a modulated infrared carrier signal, generated by a small solid-state emitter within the instrument's optical path and reflected by a prism reflector or the object under survey. The modulation pattern in the returning signal is read and interpreted by the computer in the total station. The distance is determined by emitting and receiving multiple frequencies and determining the integer number of wavelengths to the target for each frequency. Angles and distances were measured from the total station to points under survey, and the coordinates (easting, northing and elevation) of surveyed points relative to the total station position (control point) were calculated using triangulation. The geospatial information (coordinates and elevation), given as inputs to the ETS at the time of the establishment of the control point, was collected from the GPS. The field data were exported (into Shapefile, Excel and grid formats) from ETS to ArcGIS 10 (ESRI) for processing, analysis and interpretation. Moreover, since the terrain is tough and difficult, some of the portion of the study area was not covered by ETS survey, and therefore, highresolution (0.46 $\mathrm{m}$ panchromatic, $\mathrm{B}$ and $\mathrm{W} ; 1.86 \mathrm{~m}$ multispectral) QuickBird satellite data were used to overcome the problem. We also used Advanced Spaceborne Thermal Emission and Reflection Radiometer (ASTER, $30 \mathrm{~m}$ ) digital elevation model (DEM) for supplementing elevation information at locations where it was not possible to map using ETS. The Landsat 7 Enhanced Thematic Mapper plus (ETM+, $30 \mathrm{~m})$ and Landsat 8 Operational Land Manager (OLI, $30 \mathrm{~m}$ ) satellite imagery were also used to supplement the glacio-geomorphological mapping of the valley [29]. False color composites of bands 5:4:2 (30 $\mathrm{m}$ resolution) sharpened with the semitransparent grayscale image of band 8 ( $15 \mathrm{~m}$ resolution panchromatic) was used to aid the interpretation of glacial landform features. The integrated use of the field data, satellite data and DEM aids the mapping of all glacial landforms in mountainous terrain [4].

\section{Results}

The glacial, periglacial and glacio-fluvial erosional and depositional landforms, comprising the rich geomorphic diversity of the Machoi Glacier valley, were mapped in the field at 1:6000 scale using electronic total station (ETS) supplemented by GPS, remote sensing and DEM (Fig. 3) and are described below.

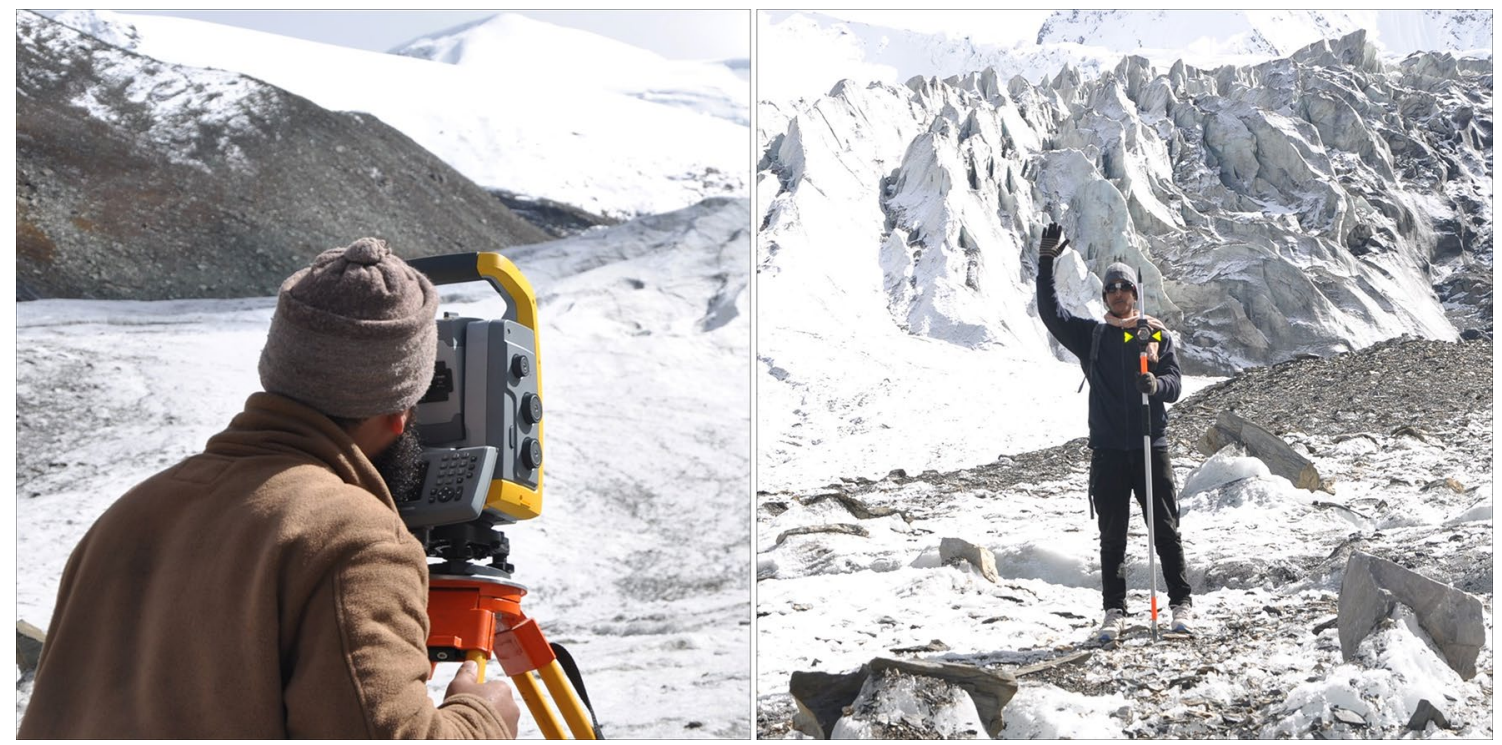

Fig. 2 Operation of the Trimble Electronic Total Station (ETS) in the field 


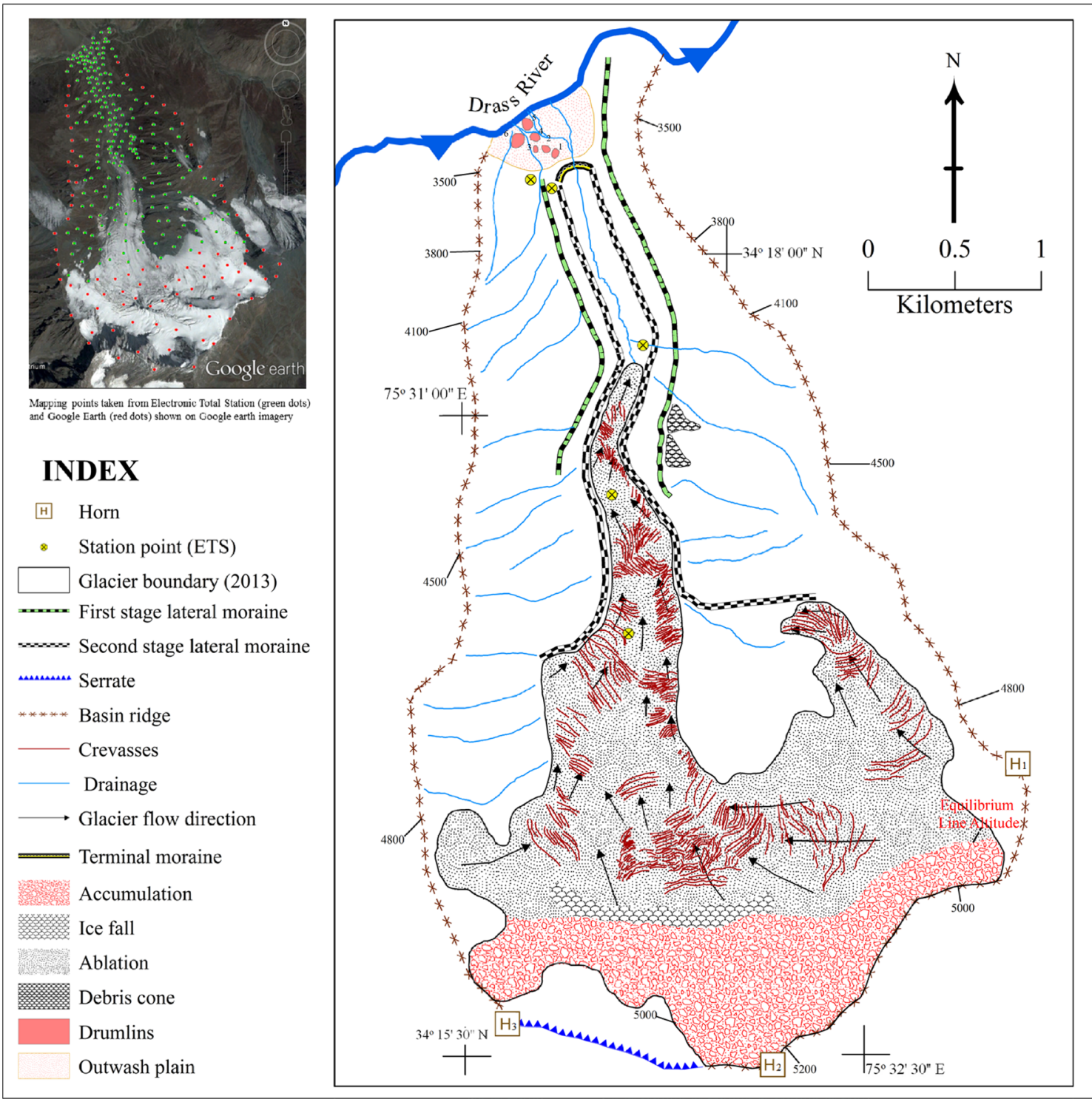

Fig. 3 Detailed glacial-landform feature map of the Machoi glacier valley. The upper left inset shows ETS based measurement points (green dots) and those based on Google Earth elevation data (red dots)

\subsection{Horn and arête}

Horn is a steep, pyramid-shaped rock summit created when glaciers erode three or more cirques into different sides of a peak [11]. Three distant horns, $\mathrm{H} 1, \mathrm{H} 2$ and $\mathrm{H} 2$, were identified and mapped in the valley with elevations of 5250,5135 and $5271 \mathrm{~m}$, respectively. Figure 4a shows the field photograph of the horn $\mathrm{H} 2$, and Fig. $4 \mathrm{~b}$ shows its appearance on the high-resolution QuickBird satellite imagery. When two glaciers flowing along the opposite sides of a mountain ridge erode the ridge both ways, they form a sharp, narrow geomorphological structure called arête [9]. The sharp edges of the arête are attributed to the wedging by frost action. A long serrate arête mapped in the Machoi Glacier valley is shown in Fig. $4 c$, $d$ and has a length of about $1.33 \mathrm{~km}^{2}$ with an elevation of about $5227 \mathrm{~m}$ (asl). The arête is located on the southernmost tip of the glacier and acts as a head wall of the glacier. The location and spatial extents of the horns and arête in the Machoi Glacier valley are shown Fig. 3 and Table 1.

\subsection{Icefalls and crevasses}

When a glacier flows over uneven bedrock, the deeper plastic ice bends and flows over bumps, stretching the brittle upper layer of ice so that it cracks, forming crevasses [19]. An icefall is a section of a glacier consisting of crevasses and towering ice pinnacles. The pinnacles form 

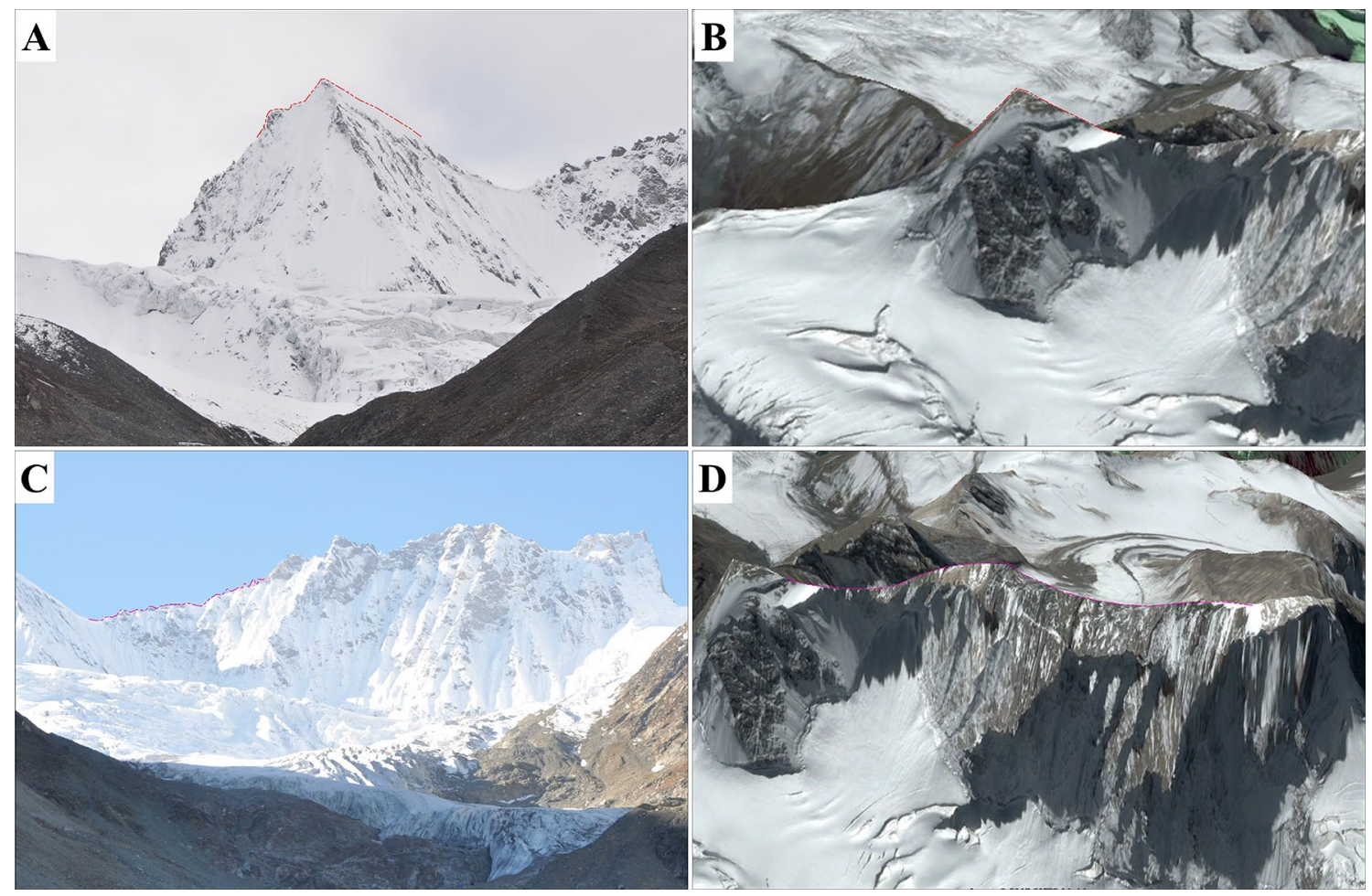

Fig. 4 a Field photograph of the horn; $\mathbf{b}$ Horn on the satellite image; $\mathbf{c}$ Field photograph of the serrate arête and $\mathbf{d}$ serrate arête seen on the satellite image

Table 1 Areal extent of the glacial-landform features in the Machoi Glacier valley

\begin{tabular}{lll}
\hline S. no. & Glacio-geomorphological feature & Dimensions \\
\hline 1 & First-stage right lateral moraine & $2661 \mathrm{~m}$ \\
2 & Second-stage right lateral moraine & $3447 \mathrm{~m}$ \\
3 & First-stage left lateral moraine & $1829 \mathrm{~m}$ \\
4 & Second-stage left lateral moraine & $3050 \mathrm{~m}$ \\
5 & Terminal moraine & $393 \mathrm{~m}$ \\
6 & Serrate & $1330 \mathrm{~m}$ \\
10 & Icefall & $13.5 \mathrm{Ha}$ \\
11 & Debris cones & $3.2 \mathrm{Ha}$ \\
12 & Drumlins (total area) & $0.67 \mathrm{Ha}$ \\
13 & Outwash plain & $16.1 \mathrm{Ha}$ \\
\hline
\end{tabular}

where ice blocks break away from the crevasse walls and rotate as the glacier moves [35]. A steep, rapid descent may result in an icefall, a piled up mass of splintered ice blocks from a series of rapidly formed crevasses as is depicted in Fig. 5a, b. Two icefalls were identified and mapped in the area and exist nearly at the equilibrium line altitude (ELA) of the glacier. Some large numbers of crevasses were observed on the glacier and were mapped as shown in Fig. 3. Crevasses show up as the valley glacier curves, and ice flows faster toward the outside of the curve than the inside [14]. Crevasses may be either longitudinal, i.e., parallel to the direction of the movement of the glacier, or transverse, perpendicular to the glacier direction. Both the transverse and longitudinal crevasses are present on the Machoi Glacier (Fig. 3). Transverse crevasses are located more toward the snout and at the bends of the glacier, and the longitudinal crevasses are located more toward the upper ablation zone of the glacier. Figure $5 c$, $d$ shows the field photograph and satellite image of the crevasses on the glacier, respectively. The width of the crevasses mapped on the glacier is from 1 to $4 \mathrm{~m}$, and length ranges from 30 to $70 \mathrm{~m}$. The location of the icefalls and the spatial distribution of the crevasses on the Machoi Glacier are shown in Fig. 3 and Table 1.

\subsection{Debris cones}

The debris cones are formed by several processes working independently or in combination such as avalanches, mass wasting and hillslope evolution [24]. The loose debris formed due to glacial deposition provides a soft target for the movement of the large boulders during these processes [7]. Two debris cones were identified and mapped in the Machoi Glacier valley and are located at the eastern slope of the valley exactly on the first-stage right lateral moraine. The areal extent of these two debris cones is 

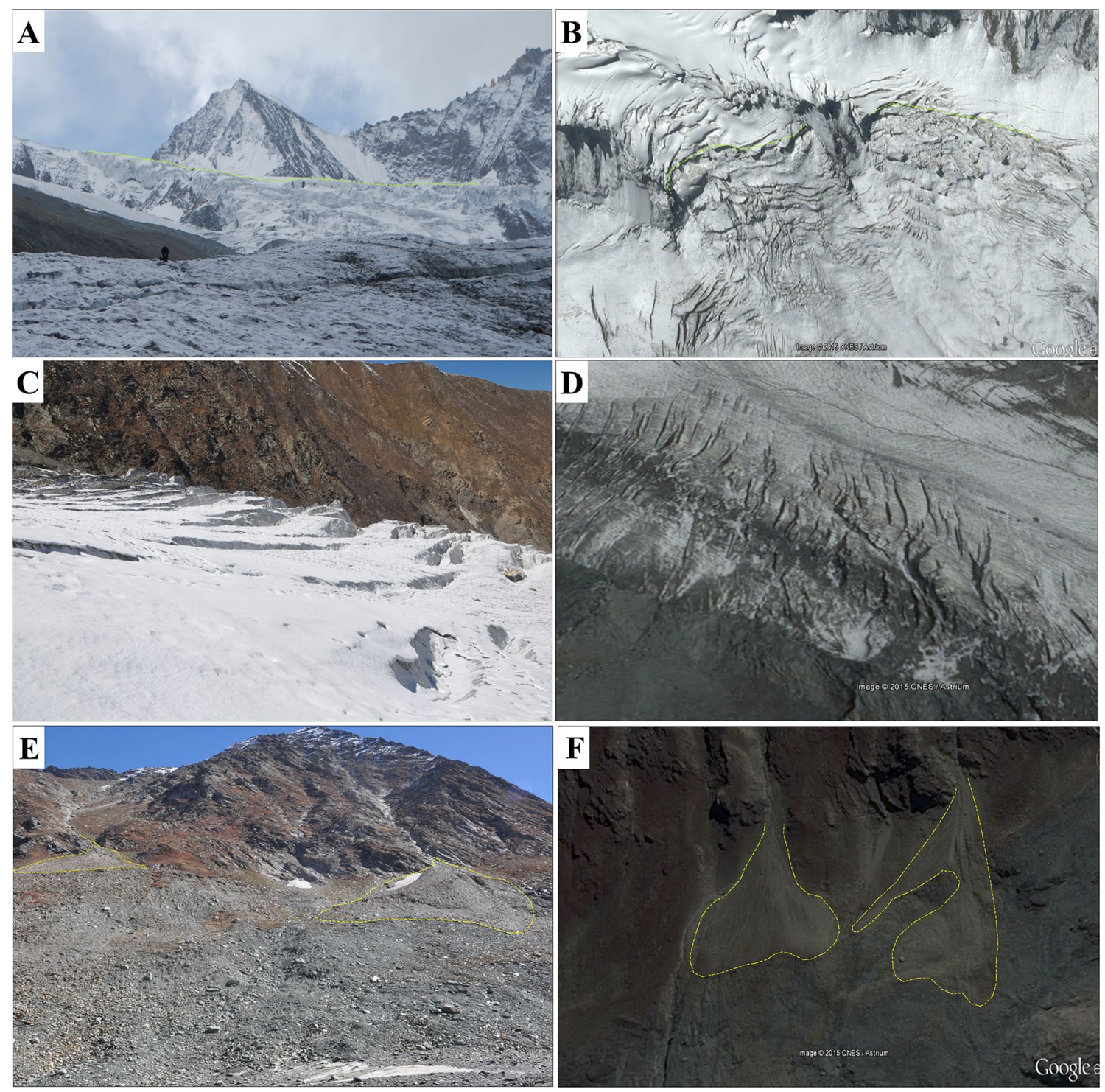

Fig. 5 a Field photograph of the ice falls in the study area. b Quickbird image of the ice falls. $\mathbf{c}$ Field photograph of the crevasses in the study area. d Crevasses on the Quickbird image. e Field photograph of the debris cones in the study area. $\mathbf{f}$ Debris cones on the Quickbird image

about 32 ha. Figure 5 e shows the debris cones pictured in the field, and Fig. $5 f$ shows the debris cone on the satellite image. The location and the spatial extent of the debris cones in the valley are shown in Fig. 3 and Table 1.

\subsection{Striations}

Striations are the long, deep and parallel grooves that are generated when rocks embedded in the glacier ice scratch the bedrock during glacier movement [33]. When glaciers melt and the striated bedrock is exposed, the markings show the direction of ice movement and are used to map the flow directions of glaciers [35]. Few locations with prominent striation markings, showing paleo-glacier flow in northwest direction that is same as the direction of the longest axes of the identified drumlins, were seen during the fieldwork in the area. The prominent striations were mapped and are shown in Fig. 3. Figure 6 shows the field photographs of the striated bed rock in the study area.

\subsection{Moraines}

Moraines are deposits of till that are left behind when a glacier recedes or that are carried on the top of a glacier [14]. There are two main types of the moraines: lateral and terminal. Lateral moraines are low ridges of rock debris formed along the margins of the glaciated valley, while terminal moraines are formed at the terminus

\section{SN Applied Sciences}



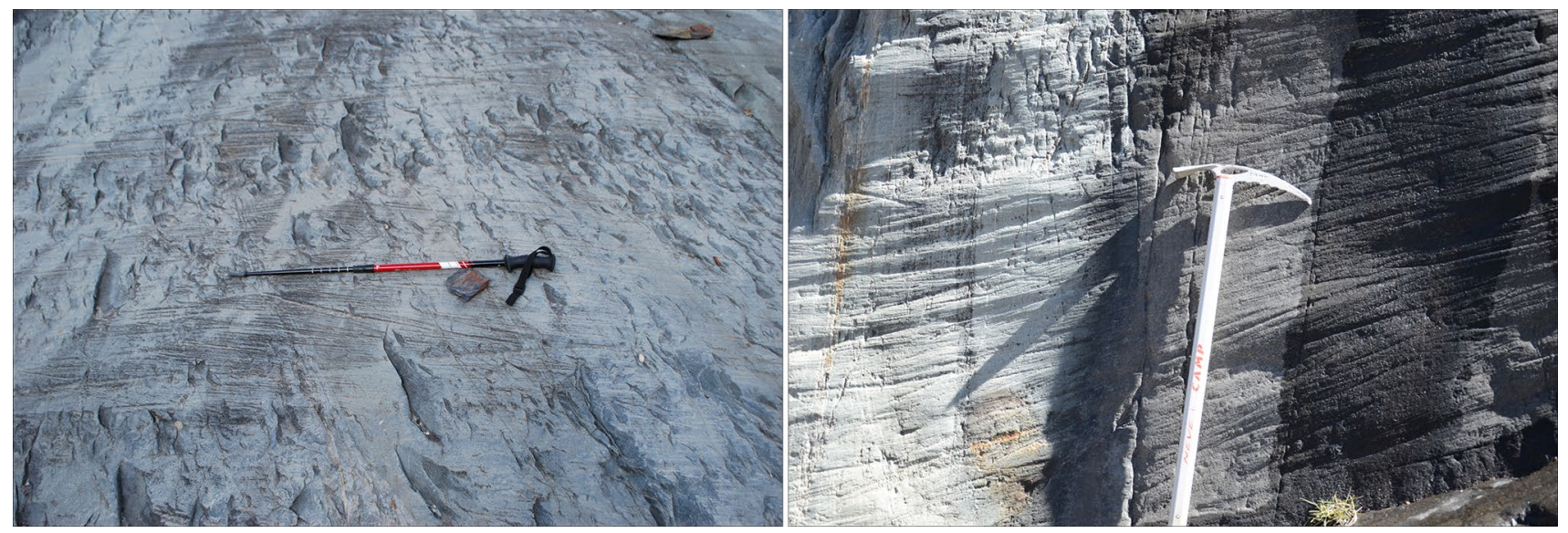

Fig. 6 Striations observed on the rocks during fieldwork

of the glaciers, where the ice front remains stationary for long period of time. Various fragmental materials are deposited at the terminal fringes of the glaciers, when the ice melts, as crescent-shaped areas of tumultuous heaps consisting of materials of varying sizes and compositions [12]. The terminal or lateral moraines are important clues to the past glacier extents and dimensions [13]. In the Himalayan glaciated regions, moraines are of greater significance in establishing the paleogeography $[18,22]$ and paleo-climate $[16,23,36]$. In the glaciated Machoi Glacier valley, there are prominent and well-preserved lateral moraines that go downhill terminate in the River Drass. The morpho-stratigraphical disposition of different moraine stages, identified, after extensive field investigation, indicated multiple glaciations in the area [10]. In the Machoi Glacier valley, two stages of lateral moraines were identified in the field and mapped as shown in Fig. 3. Both the stages of lateral moraines are well preserved on the right side (Fig. 5a, b), while the lateral moraines on the left margins of the glacier are destroyed at many places by the erosional action (Fig. 5f). The first-stage lateral moraines are shorter in length than those of the second stage as the former have been obliterated due to the erosion action. The dimensions of the moraines are provided in Table 1. Only one terminal moraine was identified and mapped in the field. The presence of two stages of lateral moraines suggests that there must have been two terminal moraines also. However, it is believed that due to the fluvial action of the glacier meltwater, the first stage of terminal moraine has eroded, making it indistinct on the ground. The mapped terminal moraine is typically crescent-shaped and connected with the second-stage lateral moraines as shown in Fig. 3. The length of the terminal moraine is about $393 \mathrm{~m}$, and its distance from the present position of the glacier snout is about $1.142 \mathrm{~km}$. The meltwater from the Machoi Glacier flows through the terminal moraine eroding it at the center (Fig. 7).

\subsection{Drumlins}

Drumlins are streamlined subglacial landforms whose long axes are parallel to the direction the glacier movement [34]. Although the presence of drumlins in the Himalayan glaciated valleys were a delusion for some time, in recent years researchers have reported these streamlined landforms in several regions of the Himalaya [1, 25, 32]. In this study, six well-preserved drumlins were identified and mapped in the field (Fig. 3) based on field interpretation supported by documented research works. The streamlined landforms were identified as drumlins on the basis of half-egg-shaped morphology with steeper stoss sides (up glacier direction) and gentler lee sides (glacier flow direction) [31]. These were mapped and are in close proximity to each other behind the terminal moraine, on western side of the outwash plain. The length, breadth, height, area and the direction of the longest axis of the drumlin are given in Table 2. Figure 8a-c shows the field photographs of the drumlins in the study area.

\subsection{Outwash plain}

Outwash is the braided, sorted and layered deposits carried by the glacier meltwater and deposited in front of the terminal moraine in the form of a large front called outwash plain [34]. The outwash plain of the Machoi Glacier valley is triangular and has an area of about $16.1 \mathrm{Ha}$ as shown in Fig. 3. The outwash plain connects to the Drass River on its northern side. The presence of braided stream in the outwash plain suggests that the eroded material from the valley gets deposited in the outwash plain due to the decrease in the stream gradient. Well-sorted silt, sand, 

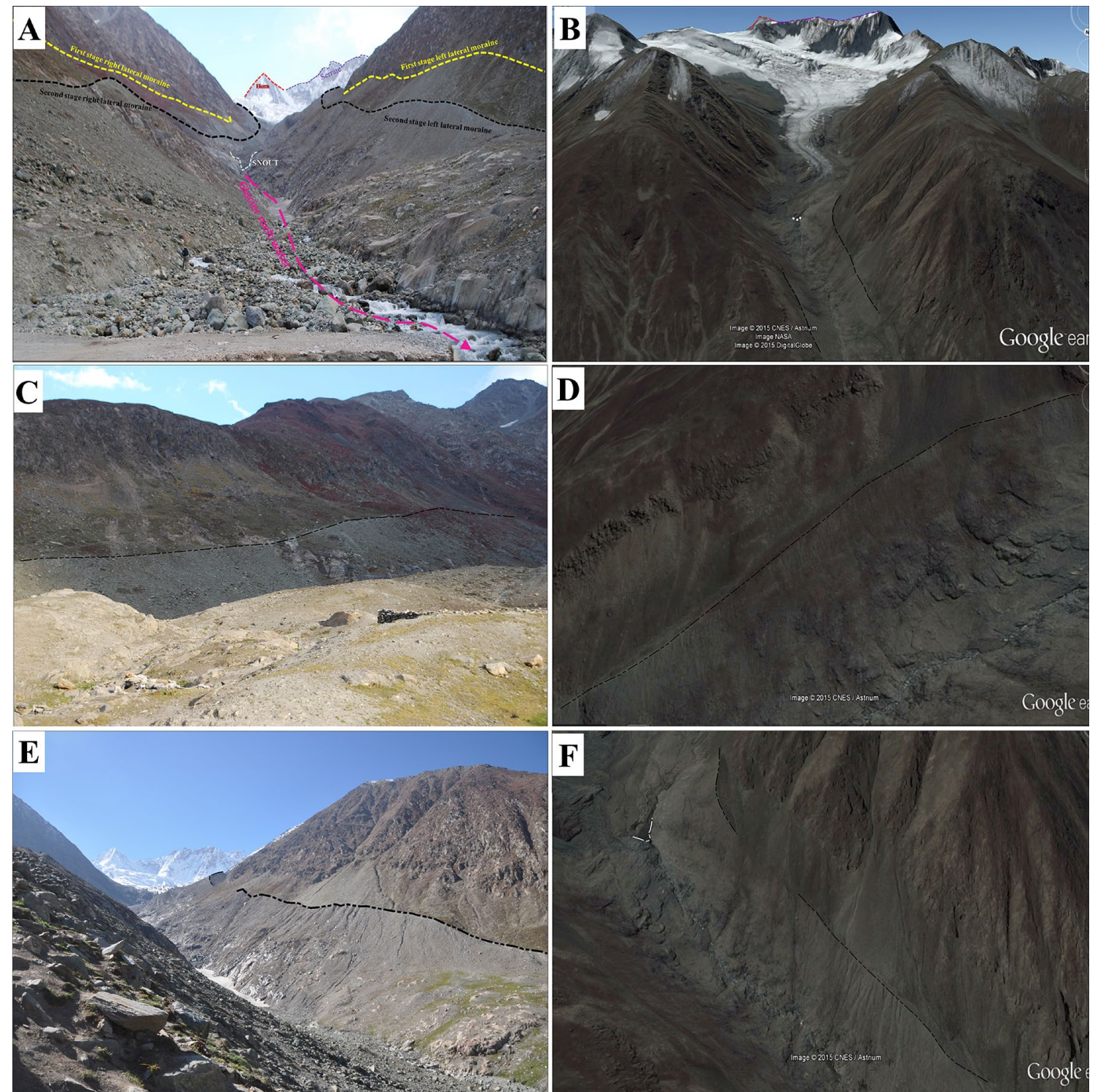

Fig. 7 a Field photograph of two stages of the right and left lateral moraines in the study. $\mathbf{b}$ Moraines and snout of the Machoi glacier on the Quickbird image. c Field photograph of the second stage right lateral moraine in the study area. $\mathbf{d}$ Second stage right lateral

moraine on the Quickbird image. e Field photograph of the second stage left lateral moraine in the study area $\mathbf{f}$ Second stage left lateral moraine on the Quickbird image

Table 2 ETS-based

dimensional characteristic features of the drumlins in the study area

\begin{tabular}{llllll}
\hline Drumlin no. & Length $(\mathrm{m})$ & Breadth $(\mathrm{m})$ & Height $(\mathrm{m})$ & Area $\left(\mathrm{m}^{2}\right)$ & $\begin{array}{l}\text { Direction of } \\
\text { the longest } \\
\text { axis }\end{array}$ \\
\hline 01 & 50.29 & 39.32 & 5.53 & 18.05 & $\mathrm{~N} \mathrm{50.16} \mathrm{W}$ \\
02 & 45.21 & 35.63 & 5.25 & 11.75 & $\mathrm{~N} \mathrm{50.78} \mathrm{W}$ \\
03 & 40.35 & 27.41 & 2.70 & 09.01 & $\mathrm{~N} 86.00 \mathrm{~W}$ \\
04 & 47.22 & 38.15 & 3.10 & 13.97 & $\mathrm{~N} \mathrm{42.13} \mathrm{W}$ \\
05 & 48.05 & 38.85 & 4.90 & 16.24 & $\mathrm{~N} \mathrm{61.57} \mathrm{W}$ \\
06 & 55.50 & 39.45 & 7.20 & 21.05 & $\mathrm{~N} \mathrm{74.00} \mathrm{W}$ \\
\hline
\end{tabular}



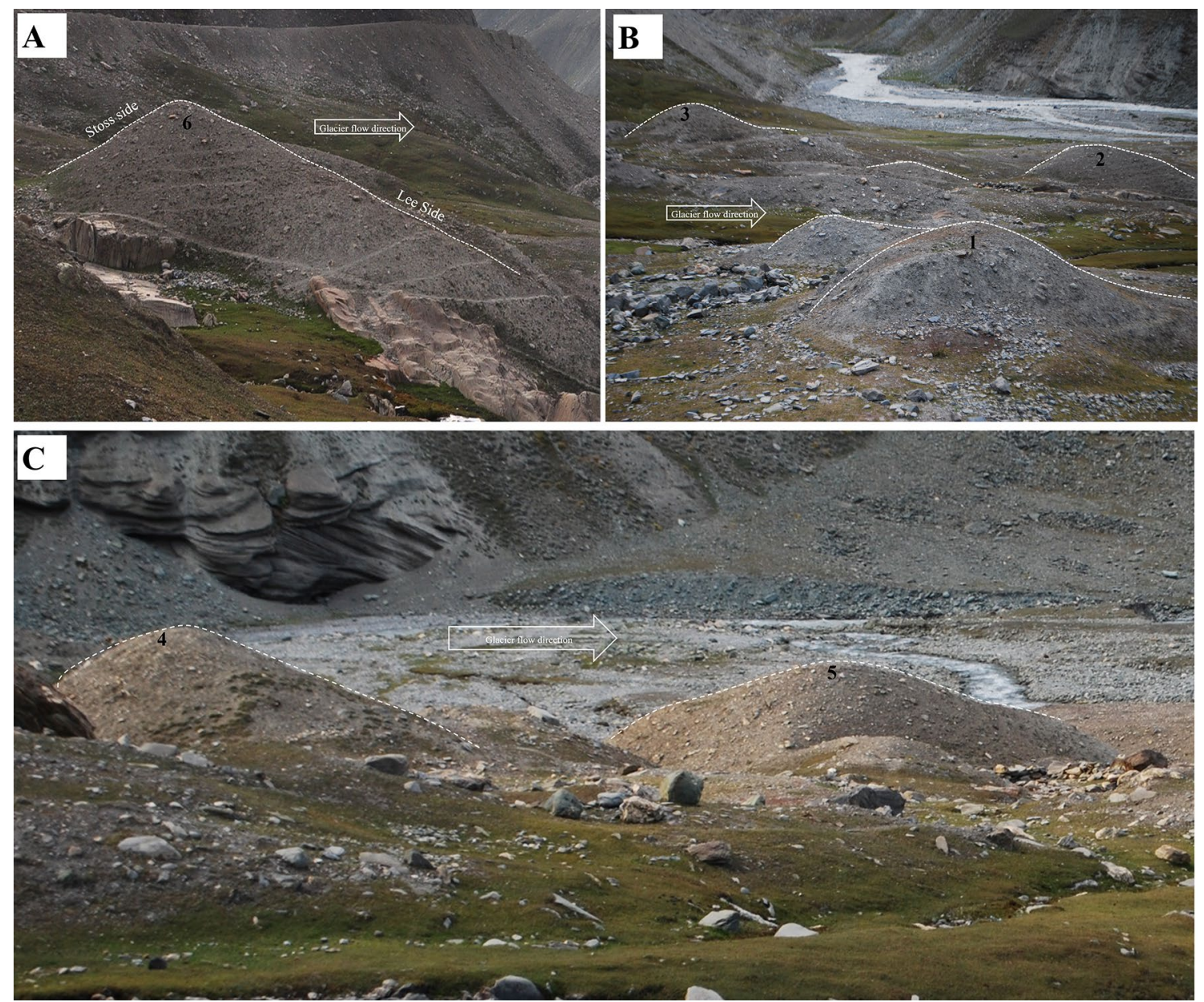

Fig. 8 Different field views of the drumlins in the study area, a Drumlin No. 6; b Drumlin No. 1, 2 and 3; c Drumlin No. 4 and 5

gravel and boulders were found in the outwash plain. Boulders are predominant in the upper parts followed by gravel, sand and silt in the lower parts. The glacial meltwater from the Machoi Glacier drains into the Drass River as shown in Fig. 3. The satellite image (Fig. 8b) shows the outwash plain of the Machoi Glacier valley.

\section{Conclusions}

The detailed geomorphological map of the Machoi Glacier valley at 1:6000 scale, prepared using the field data, remote sensing and DEM, shows the distribution and location of various glacial erosional and depositional features. The glacial landform features mapped were moraines, drumlins, serrate ridge, horns, debris cones, outwash plain and glacial striations. The ETS-based geographic area of the Machoi Glacier valley is $12.36 \mathrm{~km}^{2}$ with the valley trending in NNW-SSE direction. The data presented in this paper are useful baseline for investigating the paleo-glaciological reconstruction of NW Indian Himalayan region.

\subsection{Software}

We used high-resolution DigitalGlobe QuickBird imagery available on Google Earth portal imported via ArcGIS 10.1 software, serving as a base map for mapping locations that could not be surveyed using electronic total station (Trimble ETS). Separate Arc feature files were created to characterize each type of glacio-geomorphological feature as either a line (e.g., crevasses, small moraines) or a polygon (e.g., drumlins, glacier). All the mapping and the finalization of the map were carried out using the ArcMap 10.1.

\subsection{Map design}

As the aim of the present study was to lay down a baseline geomorphological map that would serve as a guide for the selection of the dating samples for paleo-climate 
reconstruction of the region, the map was drawn at a 1:6000 scale using data from ETS and high-resolution DigitalGlobe imagery. The reference system is the Universal Transverse Mercator projection for zone 43 north. There are many locations on the geomorphological map that have been clearly provided with the latitude/longitude information to serve as ground control points (GCPs) easy georeferencing in any image processing software. We applied standard color palettes and systematics for characterizing different glacial basins. Since all the layers of information are stored in separate GIS layers, any other layer combination and layout for the map is possible.

Acknowledgements We thankfully acknowledge the help of Commanding Officer (CO, Army) of the Gumri Camp and the local police authorities of the Drass, Kargil during the field-work. Special thanks to the editor (Dr. Clifford Chuwah) and two anonymous reviewers for their valuable comments to improve this article. We thank the SOI, NOAA, U.S. Navy, NGA and GEBCO for providing data on the DigitalGLobe portal.

Funding The work was conducted as part of the Department of Science and Technology (DST), Government of India-sponsored consortium project titled "Himalayan Cryosphere: Science and Society," and the financial assistance received from the department under the project to accomplish this research is thankfully acknowledged.

\section{Compliance with ethical standards}

Conflict of interest The authors declare that they have no conflict of interest.

\section{References}

1. Benn DI, Owen LA (2002) Himalayan glacial sedimentary environments: a framework for reconstructing and dating former glacial extents in high mountain regions. Quat Int 97-98:3-26

2. Bhambri R, Bolch T (2009) Glacier mapping: a review with special reference to the Indian Himalayas. Prog Phys Geogr 33(5):672-704

3. Bishop M, Shroder JF (2004) Geographic information science and mountain geomorphology. Springer, Berlin

4. Bishop MP, James LA, Shroder JF, Walsh SJ (2012) Geospatial technologies and digital geomorphological mapping: concepts, issues and research. Geomorphology 137(1):5-26

5. Blaszczynski JS (1997) Landform characterization with geographic information systems. Photogramm Eng Remote Sens 63(2):183-191

6. Bondarev LG, Gobedzhishvili RG, Solomina OS (1997) Fluctuations of local glaciers in the southern ranges of the former USSR: 18,000-8000 BP. Quat Int 38:103-108

7. Chopra S (1990) A geological cum geomorphological framework of Haryana and adjoining areas for landuse appraisal using landsat imagery. J Indian Soc Remote Sens 18(1):15-22

8. Dar RA, Jaan O, Murtaza KO, Romshoo SA (2017) Glacial-geomorphic study of the Thajwas glacier valley, Kashmir Himalayas, India. Quat Int 444(A):157-171

9. Drewry DJ (1986) Glacial geologic processes. Edward Arnold, Baltimore
10. Fu P, Stroeven AP, Harbor JM, Hättestrand C, Heyman J, Caffee MW, Zhou L (2013) Paleoglaciation of Shaluli Shan, southeastern tibetan plateau. Quat Sci Rev 64:121-135

11. Hambrey MJ (1994) Glacial environments. UCL Press, London

12. Harbor J (1993) Glacial geomorphology: modeling processes and landforms. Geomorphology 7:129-140

13. Hubbard B, Glasser N (2005) Field techniques in glaciology and glacial geomorphology. Wiley, US

14. Huggett R (2007) Fundamentals of geomorphology. Routledge, Abingdon

15. Kamp U, Haserodt K, Shroder JF (2004) Quaternary landscape evolution in the eastern Hindu Kush, Pakistan. Geomorphology $57(1): 1-27$

16. Knight J, Harrison S, Jones DB (2019) Rock glaciers and the geomorphological evolution of deglacierizing mountains. Geomorphology 324:14-24

17. Kuhle M (1997) New findings concerning the Ice Age (Last Glacial Maximum) glacier cover of the East-Pamir, of the Nanga Parbat up to the Central Himalaya and of Tibet, as well as the age of the Tibetan Inland Ice. GeoJournal 42(2):87-257

18. Lehmkuhl F, Owen LA (2005) Late quaternary glaciation of Tibet and the bordering mountains: a review. Boreas 34:87-100

19. Mahapatra GB (1994) A text book of physical geology. CBS publications, Chennai

20. Mehta M, Majeed Z, Dobhal DP, Srivastava P (2012) Geomorphological evidences of post-LGM glacial advancements in the Himalaya: a study from Chorabari Glacier, Garhwal Himalaya, India. J Earth Syst Sci 121(1):149-163

21. Napieralski J, Harbor J, Li Y (2007) Glacial geomorphology and geographic information systems. Earth Sci Rev 85(1):1-22

22. Owen LA, Finkel RC, Barnard PL, Haizhou M, Asahi K, Caffee MW, Derbyshire E (2005) Climatic and topographic controls on the style and timing of Late Quaternary glaciation throughout Tibet and the Himalaya defined by ${ }^{10} \mathrm{Be}$ cosmogenic radionuclide surface exposure dating. Quat Sci Rev 24:1391-1411

23. Owen LA, Finkel RC, Caffee MW (2002) A note on the extent of glaciation throughout the Himalaya during the global Last Glacial Maximum. Quat Sci Rev 21(1-2):147-157

24. Pankaj A, Kumar P, Mishra A (2012) Extraction of Glacio-geomorphological units of tons river watershed based on remote sensing techniques. Indian Soc Remote Sens 40(4):725-734

25. Pant RK, Phadtare NR, Chamyal LS, Juyal N (2005) Quaternary deposits in Ladakh and Karakoram Himalaya: a treasure trove of the palaeoclimate records. Current Sci 21:1789-1798

26. Phartiyal B, Sharma A, Upadhyay R, Sinha AK (2005) Quaternary geology, tectonics and distribution of palaeo-and present fluvio/glacio lacustrine deposits in Ladakh, NW Indian Himalaya-a study based on field observations. Geomorphology 65(3):241-256

27. Raina VK, Srivastava D (2008) Glacier atlas of India. Geological Society of India, Bangalore

28. Rashid I, Romshoo SA, Abdullah T (2017) The recent deglaciation of Kolahoi valley in Kashmir Himalaya, India in response to the changing climate. J Asian Earth Sci 138:38-50

29. Rashid I, Romshoo SA, Hajam JA, Abdullah T (2016) A semi-automated approach for mapping geomorphology in mountainous Terrain, Ferozpora watershed (Kashmir Himalayas). J Geol Soc India 88(2):206-212

30. Richards BW, Owen LA, Rhodes EJ (2000) Timing of late quaternary glaciations in the Himalayas of northern Pakistan. J Quat Sci 15(3):283-297

31. Saha S, Sharma MC, Murari MK, Owen LA, Caffee MW (2016) Geomorphology, sedimentology and minimum exposure ages of streamlined subglacial landforms in the NW Himalaya, India. Boreas 45:284-303 
32. Schomacker A, Kruger J, Kjær KH (2006) Ice-cored drumlins at the surge-type glacier Bruarjokull, Iceland: a transitional-state landform. J Quat Sci 21:85-93

33. Sugden DE, John BS (1976) Glaciers and landscape. Arnold, London

34. Summerfield MA (1991) Global geomorphology. An introduction to the study of Landforms. Routledge, London

35. Thompson GR, Turk J (1997) Introduction to physical geology, 2nd edn. Brooks/Cole.19/25
36. Wei Z, Zhijiu C, Yonghua L (2006) Review of the timing and extent of glaciers during the last glacial cycle in the bordering mountains of Tibet and in East Asia. Quat Int 154-155:32-43

Publisher's Note Springer Nature remains neutral with regard to jurisdictional claims in published maps and institutional affiliations. 